\title{
Perilaku Inflasi 33 Propinsi di Indonesia
}

\author{
Birgitta Dian Saraswati ${ }^{1, *}$, David Kaluge ${ }^{2}$
}

${ }^{1,2}$ Universitas Brawijaya Malang

\section{Informasi Artikel}

Sejarah artikel:

Diterima Februari 2016

Disetujui Maret 2017

Dipublikasikan Maret 2017

\section{Keywords:}

Inflation,

Food Price,

Gross Regional Domestik

Product,

Government Expenditure

\begin{abstract}
A B S TR ACT
This study aims to identify the effect of food prices and the factors of demand side on the inflation rate in the 33 provinces in Indonesia. Using fixed effect panel data regression model, our result show that inflation in 33 provinces in Indonesia are caused by demand-side factors (gross regional domestik product and government expenditure) as well as supply-side factors, namely food prices in this case the price of rice. The policy implication of this study is that monetary policy by controlling the money supply is still effective for achieving the goal of price stability. However, monetary policy alone will not be effective to achieve the inflation target. Required policy coordination among agencies or departments in order to ensure the availability of basic necessities such as rice commodities.
\end{abstract}




\section{Pendahuluan}

Stabilitas harga merupakan salah satu tujuan yang ingin dicapai dalam suatu perumusan kebijakan makro ekonomi disamping tujuan lain yaitu pertumbuhan ekonomi yang berkelanjutan, penciptaan kesempatan kerja dan surplus neraca pembayaran. Hal ini disebabkan karena stabilitas harga yang tercermin dari tingkat inflasi mempunyai dampak yang cukup besar bagi kesejahteraan masyarakat melalui dampaknya terhadap pertumbuhan ekonomi.

Pengalaman krisis ekonomi yang dialami Indonesia pada tahun 1997, mengingatkan akan sejarah perekonomian Indonesia yang pernah mengalami hyperinflation pada masa orde lama. Inflasi pada saat itu mencapai lebih dari $600 \%$. Tingginya tingkat inflasi di Indonesia kembali dialami pada tahun 1998 sebagai dampak dari krisis ekonomi yang dimulai pada kuartal dua tahun 1997. Krisis ini diawali dari krisis mata uang Bath Thailand yang menular ke dalam perekonomian Indonesia (contagion effect).
Dampak dari tingginya tingkat inflasi pada tahun 1998 yang mencapai 75,27 persen berdampak pada pertumbuhan ekonomi di Indonesia. Pada tahun 2008 pertumbuhan ekonomi Indonesia mengalami titik terendah selama dalam periode orde baru yaitu berada pada tingkat $-13,13$ persen.

Tingginya tingkat inflasi di tahun 1998 membuat daya beli masyarakat menurun sehingga konsumsi masyarakat turun. Turunnya daya beli yang menyebabkan rendahnya konsumsi menyebabkan banyak perusahaan mengalami kebangkrutan. Sehingga dampak selanjutnya adalah output dalam perekonomian akan menurun yang terlihat dari pertumbuhan ekonomi yang menurun tajam di tahun 1998. Hal ini mengindikasikan besarnya dampak inflasi terhadap perekonomian. Oleh sebab itu pemerintah melalui kebijakan makro menetapkan stabilitas harga sebagai salah satu tujuannya. Dalam rangka tercapainya tujuan stabilitas harga maka perlu dikaji faktor-faktor yang mempengaruhi inflasi di

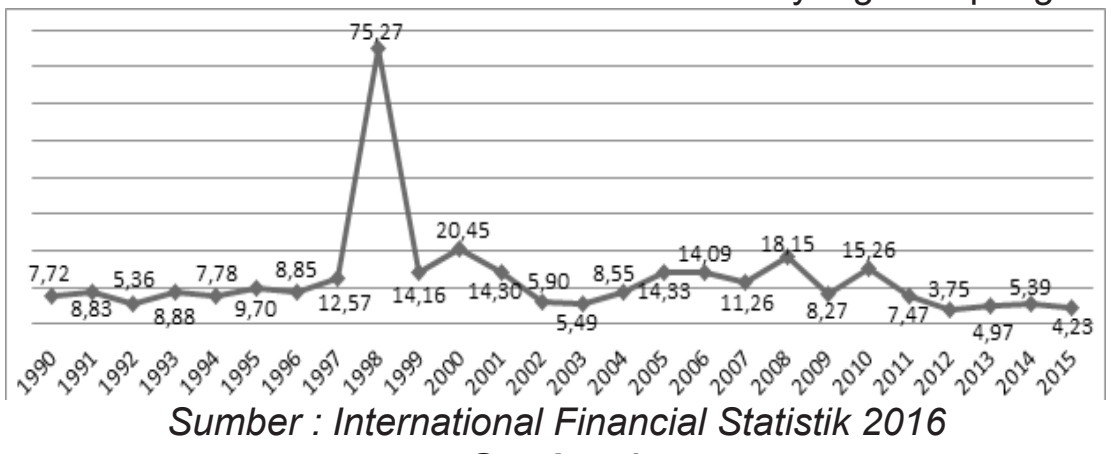

Gambar 1

Tingkat inflasi di Indonesia 1990-2015 (dalam persen)

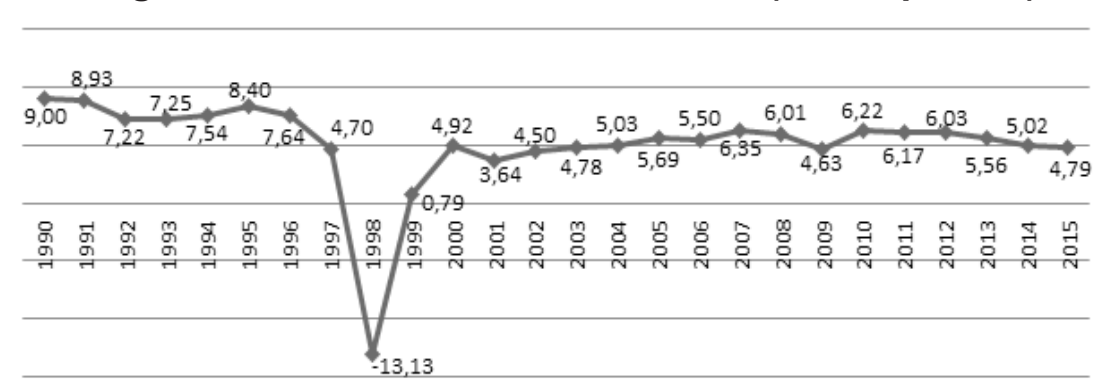

Sumber: International Financial Statistik 2016

Gambar 2

Pertumbuhan ekonomi Indonesia 1990-2015 (dalam persen) 
Indonesia.

Ada banyak penelitian sebelumnya untuk mengkaji faktor-faktor penyebab inflasi yang telah dilakukan. Secara teori inflasi bisa disebabkan dari sisi permintaan (demand pull inflation) dan dari sisi penawaran (cost push inflation). Dari sisi permintaan, jumlah uang beredar atau variabel moneter merupakan faktor yang dapat menyebabkan terjadinya inflasi melalui peningkatan permintaan agregat. Hal ini dibuktikan oleh hasil penelitian yang telah dilakukan oleh Evelyn (2012); Bari Bilqin (2013); Cavoshzadeh (2012) yang memberikan hasil bahwa jumlah uang beredar mempunyai pengaruh positif terhadap inflasi di Nigeria, Turki dan Iran. Namun berbeda dengan yang terjadi di Jordan. Penelitian Jaradat (2011) memberikan hasil bahwa inflasi di Jordan tidak dipengaruhi oleh jumlah uang beredar. Masih merupakan variable moneter, tingkat bunga juga merupakan variable yang berpengaruh terhadap inflasi. Hasil penelitian Bari (2012) memberikan hasil bahwa tingkat bunga mempunyai pengaruh negatif terhadap inflasi yang terjadi di Turkey. Namun berbeda dengan penelitian Bari (2012), penelitian Aurangzeb (2012) menunjukkan bahwa tingkat bunga mempunyai pengaruh positif terhadap inflasi di Pakistan. Selain jumlah uang beradar dan tingkat bunga, variable moneter yang terbukti mempunyai pengaruh terhadap inflasi adalah nilai tukar seperti hasil penelitian Cerra (2016) dan Aurangzeb (2012), ekspektasi harga seperti hasil penelitian Evelyn (2012), permintaan impor seperti hasil penelitian Chavoshzadeh (2012) dan Pendapatan nasional seperti hasil penelitian Cavoshzadeh (2012) dan Aurangzeb (2012).

Selain faktor-faktor dari sektor moneter, inflasi juga disebabkan oleh sektor riil. Penelitian Coutinho (2012) menyatakan bahwa inflasi yang terjadi di Negara-negara Southern Mediterranean sangat dipengaruhi oleh defisit fiskal
Negara. Mendukung penelitian Coutinho (2012), penelitian yang dilakukan oleh Fan (2016) memberikan hasil bahwa kebijakan fiskal mempunyai peran besar terhadap terjadinya inflasi di Inggris. Masih dari sektor riil sebagai penyebab inflasi, penelitian Cerra (2016) memberikan hasil bahwa harga minyak dunia sebagai produksi dari penerimaan negara terbukti berpengaruh terhadap tingkat inflasi di Venezuela. Terkait dengan perubahan iklim secara ekstrim yang terjadi dan dialami oleh semua Negara di dunia, maka pergerakan harga komoditas pertanian terutama bahan pangan merupakan faktor yang sangat kuat berpotensi mendorong inflasi. Hasil penelitian Rangasamy (2010) memberikan hasil bahwa pergerakan harga pangan memegang peranan penting dalam pembentukan inflasi di South Africa. Menguatkankan hasil penelitian Rangasamy (2010), penelitian Adam (2012) memberikan hasil bahwa inflasi umum yang terjadi di Tanzania, 60 persen disumbang oleh harga pangan dan harga minyak dunia. Dalam melihat pengaruh harga pangan terhadap inflasi, penelitian sebelumnya melihat dari sumbangan harga pangan terhadap total inflasi. Yang membedakan penelitian ini dengan penelitian sebelumnya penelitian ini bertujuan melihat besarnya pengaruh harga pangan (harga cabe dan harga beras) terhadap tingkat Inflasi di 33 propinsi di Indonesia. Selain juga ingin mengidentifikasi pengaruh sisi permintaan yaitu pendapatan dan pengeluaran pemerintah terhadap tingkat inflasi di 33 propinsi di Indonesia.

Dengan latar belakang fenomena tingkat inflasi di Indonesia sejak krisis yang dialami pada tahun 1997 dan adanya research gap dari penelitian sebelumnya, menjadi menarik untuk mengkaji faktor-faktor yang berpengaruh terhadap tingkat inflasi di Indonesia. Sehingga pada akhirnya dapat teridentifikasi faktor-faktor yang berpengaruh terhadap tingkat inflasi di Indonesia. Hal ini akan berguna bagi penyusunan kebijakan dalam rangka penca- 
paian target inflasi sebagai kerangka kebijakan moneter di Indonesia.

Inflasi menurut Mishkin (2013)

didefinisikan sebagai kenaikan tingkat harga secara umum dan terus menerus. Didalam menjelaskan terjadinya inflasi dalam perekonomian, terdapat dua pandangan besar yaitu pandangan monetaris dan pandangan Keynesian. Menurut kaum monetaris (Mishkin, 2013), inflasi didalam perekonomian terjadi karena adanya pertumbuhan jumlah uang beredar yang terlalu tinggi. Kenaikan jumlah uang beredar akan menyebabkan peningkatan dalam permintaan agregat. Kaum monetaris berpendapat bahwa yang dapat menyebabkan pergeseran kurva permintaan agregat adalah hanya jumlah uang yang beredar. Sehingga kenaikan jumlah uang beredar akan berdampak pada kenaikan permintaan agregat. Jika kenaikan permintaan agregat tidak diikuti oleh kenaikan penawaran agregat maka terjadilah inflasi karena tarikan permintaan (demand pull inflation).

Kaum Keynesian membenarkan pendapat kaum monetaris bahwa inflasi yang terjadi dalam perekonomian disebabkan oleh pertumbuhan jumlah uang beredar yang terlalu tinggi. Namun demikian kaum Keynesian (Mishkin, 2015) menyatakan bahwa pergeseran kurva permintaan agregat tidak hanya disebabkan oleh jumlah uang beredar saja tetapi juga oleh adanya kebijakan fiskal melalui variable pengeluaran pemerintah. Namun demikian kenaikan pengeluaran pemerintah (kebijakan fiskal) secara individu tidak dapat menyebabkan inflasi, tetapi hanya menyebabkan kenaikan harga secara temporer. Kenaikan pengeluaran pemerintah yang disertai dengan kebijakan penambahan jumlah uang beredar yang akan menyebabkan terjadinya inflasi dalam perekonomian.

Banyak penelitian yang berkaitan dengan inflasi yang telah dilakukan sebelumnya. Evelyn (2012) meneliti inflasi di
Negara Nigeria pada periode tahun 19702010 dengan pendekatan Error Corection Model. Penelitian tersebut memberikan hasil bahwa ekspektasi inflasi dan jumlah uang beredar terbukti berpengaruh terhadap inflasi di Nigeria dan perilaku inflasi di Nigeria mengarah pada teori inflasi dari Milton Friedman (Monetaris). Mendukung penelitian Evelyn (2012), penelitian terhadap tingkat inflasi di Republik Iran yang dilakukan oleh Chavoshzadeh (2012) dengan metode Vector Auto Regression (VAR) dengan periode waktu 19712005 memberikan hasil bahwa jumlah uang beredar (M2), Pendapatan Nasional (GDP) dan Indeks harga Impor berpengaruh secara positif terhadap tingkat inflasi di Iran. Hasil yang berbeda ditunjukkan oleh penelitian Jaradat, Mahmood (2011) yang menunjukkan bahwa jumlah uang beredar tidak berpengaruh terhadap inflasi di Jordan. Inflasi di Jordan dipengaruhi oleh eksternal shock yaitu melalui variable ekspor dan worker remmitance.

Dengan pendekatan yang berbeda Bari (2013) meneliti inflasi di Turkey dengan pendekatan Vector Error Correction Model (VECM) dengan periode waktu 20022012. Temuan dari penelitian ini adalah bahwa Inflasi yang terjadi di Turkey kuat dipengaruhi oleh tingkat bunga dan Output Gap dimana tingkat bunga mempunyai respon negatif terhadap inflasi di Turkey, sedangkan output Gap mempunyai respon positif terhadap tingkat inflasi di Turkey.

Selain dari sisi moneter, sisi fiskal juga berpengaruh terhadap inflasi dalam suatu perekonomian. Seperti ditunjukkan oleh penelitian Coutino (2012) yang melakukan penelitian faktor yang menyebabkan inflasi di Negara-negara Southern Mediterranean. Hasil dari penelitian tersebut adalah defisit fiskal sangat berpengaruh terhadap tingkat inflasi selain defisit transaksi berjalan juga berpengaruh terhadap tingkat inflasi di Negara-negara Southern Mediterranean. Masih berkaitan dengan pengaruh defisit fiskal ter- 
hadap tingkat inflasi, Aurangzeb (2012) meneliti pengaruh defisit fiskal, pendapatan nasional (GDP), nilai tukar, tingkat bunga dan pengangguran terhadap inflasi di Pakistan dengan pendekatan regresi berganda pada periode 1981-2010. Memberikan hasil bahwa pendapatan nasional mempengaruhi inflasi di Pakistan dengan arah negatif. Sedangkan defisit fiskal, nilai tukar, tingkat bunga dan pengangguran mempengaruhi tingkat inflasi dengan arah positif. Menguatkan hasil-hasil penelitian sebelumnya, Fan (2015) dengan pendekatan Vector Error Corection Model (VECM) memberikan hasil bahwa Defisit fiskal berpengaruh terhadap tingkat inflasi di Inggris.

Selain dari goncangan moneter dan fiskal, inflasi juga dipengaruhi oleh goncangan harga minyak dunia dan harga pangan (volatile food). Penelitian Cerra (2016) yang meneliti pengaruh sistem nilai tukar, jumlah uang beredar dan harga minyak dunia terhadap inflasi di Venezuela. Hasil dari penelitian tersebut menunjukkan bahwa harga minyak dunia berpengaruh secara positif terhadap tingkat inflasi di Venezuela. Selain itu sistem nilai tukar yang ditetapkan (Fixed Exchane Rate) pada saat kebijakan devaluasi terbukti mampu menurunkan tingkat inflasi di Venezuela. Penelitan berbeda dilakukan oleh Rangasamy (2010) dan Adam (2012). Rangasamy (2010) meneliti hubungan harga pangan terhadap inflasi di Afrika Utara. Dengan metode probit dan dengan periode 1971-2008, penelitian tersebut memberikan hasil bahwa pergerakan harga pangan memegang peranan penting dalam pembentukan inflasi di Afrika Utara. Sedangkan Adam (2012) memeneliti sumbangan harga pangan terhadap pembentukan inflasi di Tanzania dengan metode Multiple Determinant, Single Equation Model. Penelitian ini memberikan hasil bahwa inflasi umum yang terjadi di Tanzania, sebesar 60 persen disumbang oleh harga pangan.

Berdasarkan latar belakang dan studi literature diatas maka Hipotesis yang dirumuskan dalam penelitian ini adalah sebagai berikut; $\mathrm{H}_{1}$ : Produk domestik regional bruto (pendapatan) berpengaruh terhadap tingkat Inflasi 33 propinsi di Indonesia; $\mathrm{H}_{2}$ : Pengeluaran pemerintah daerah berpengaruh terhadap tingkat inflasi 33 propinsi di Indonesia; $\mathrm{H}_{3}$ : Harga cabe berpengaruh terhadap tingkat inflasi 33 propinsi di Indonesia; $\mathrm{H}_{4}$ : Harga beras berpengaruh terhadap tingkat inflasi 33 propinsi di Indonesia.

\section{Metode Penelitian \\ Jenis Dan Sumber Data}

Penelitian ini menggunakan data kuantitatif yang menurut aras pengukurannya termasuk ke dalam data rasio yaitu data inflasi, data produk domestik bruto (PDRB) untuk proksi pendapatan, data pengeluaran pemerintah daerah data harga cabe dan data harga beras. Sedangkan menurut waktu, data ini menggunakan data panel yaitu gabungan antara data cross section yaitu data dari 33 propinsi di Indonesia dan runtut waktu (time series) dengan periode waktu 2010-2012.

Data yang digunakan dalam penelitian ini meliputi data: (a) Inflasi merupakan kenaikan harga secara umum dan terus menerus yang dalam penelitian ini menggunakan data indeks harga konsumen di ibukota propinsi di 33 propinsi di Indonesia. Data diperoleh dari Kajian Ekonomi dan Keuangan Regional yang diterbitkan oleh Bank Indonesia (www. bi.go.id); (b) Pendapatan dalam penelitian ini merupakan total produk domestik bruto (PDRB) berdasarkan harga konstan 2010; (c) Pengeluaran pemerintah merupakan realisasi pengeluaran pemerintah daerah di 33 propinsi di Indonesia. Data diperoleh dari Badan Pusat Statistika (BPS); (d) Data rata-rata harga cabe di ibukota propinsi di Indonesia. Data diperoleh dari statistik harga komoditas pertanian 2015; (e) Data rata-rata harga beras di ibukota propinsi di Indonesia. Data diperoleh dari 
statistik harga komoditas pertanian 2015.

\section{Teknik Analisis}

Pada penelitian ini, model yang digunakan adalah regresi data panel karena dalam penelitian ini menggunakan data gabungan antara data time series dan data cross section (Gujarati, 2003). Hubungan antara variabel inflasi dengan pendapatan, pengeluaran pemerintah, harga cabe dan harga beras di 33 propinsi di Indonesia dalam penelitian ini dirumuskan dalam sebuah fungsi sebagai berikut :

$$
P t=f(Y t, \text { Gt, Pcabet, Pberast }) \text {. }
$$

Fungsi di atas dituliskan sebagai persamaan ekonometrika model regresi data panel sebagai berikut :

$P_{i t}=\beta_{0}+\beta_{1} Y_{i t}+\beta_{2} G_{i t}+\beta_{3} P_{c a b e}+$ $\beta_{4}$ Pberas $_{i t}+u_{\text {it }}$

Dimana, $P_{i t}$ : Tingkat Inflasi ibukota propinsi; $Y_{i t}$ : Pendapatan (PDRB); $G_{i t}$ : Pengeluaran Pemerintah Daerah; Pcabe it: Harga cabe per propinsi; Pberas it: Harga beras per propinsi; $u_{i t}$ : Residual; $\beta_{0}$ : Konstanta; $\beta_{1}, \beta_{2}, \beta_{3}$ : Koefisien regresi. pada setiap daerah dan setiap periode waktu. Oleh karena itu, dalam mengestimasi persamaan (1) diatas akan sangat bergantung pada asumsi tentang intersep, koefisien slope dan variable gangguan (Widarjono, 2016). Untuk menentukan metode estimasi yang tepat maka dilakukan Chow Test dan Hausman Test. Chow test atau $F$ test dilakukan untuk membandingkan model mana yang terbaik antara Commond Effect dengan Fixed Effect.

Dari hasil uji Chow Test di bawah dapat terlihat bahwa nilai probability Cross-Section $\mathrm{F}$ adalah sebesar 0.0000 , nilai ini lebih kecil daripada nilai alpha 0,05 . Sehingga keputusan yang diambil adalah menerima $\mathrm{Ha}$ yang berarti model Fixed Effect lebih baik. Dimana; Ho: model commond effect lebih baik dan $\mathrm{Ha}$ : model Fixed Effect lebih baik. Langkah selanjutnya adalah membandingkan model Fixed effect dengan model Randam Effect, agar didapat model yang benar-benar bagus. Untuk itu dilakukan Uji Hausman (Hausman Test).

Tabel 1

Hasil Uji Chow Test

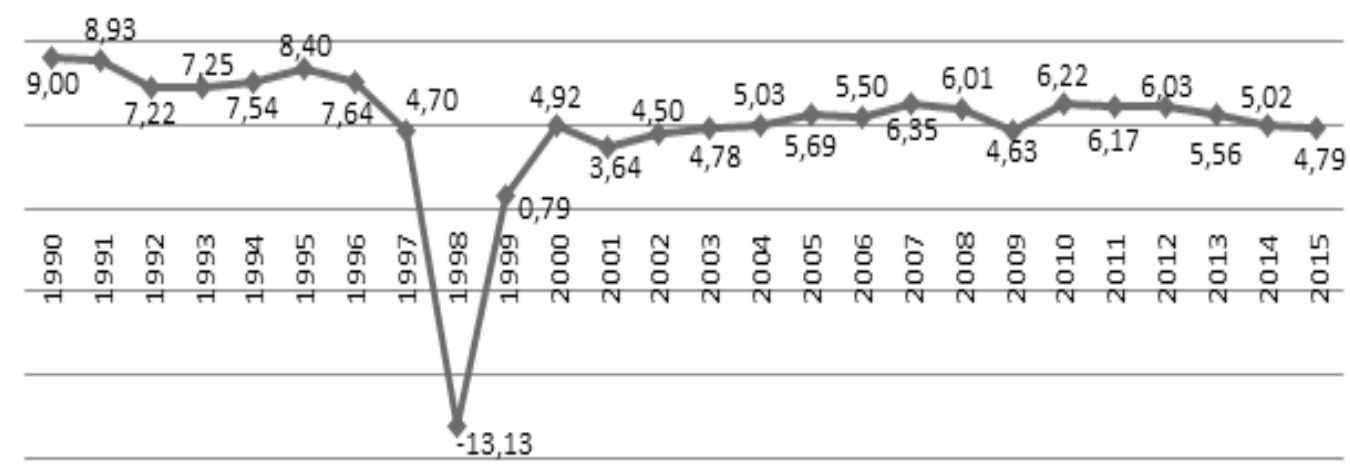

Secara umum dengan menggunakan regresi data panel model akan menghasilkan intersep dan koefisien yang berbeda
Dari hasil uji Hausman Test di bawah dapat terlihat bahwa nilai probability Cross-Section Random adalah sebesar 
0.0000 , nilai ini lebih kecil daripada nilai positif dan signifikan terhadap tingkat alpha 0,05. Sehingga keputusan yang di- inflasi propinsi di Indonesia. Sedangambil adalah menerima Ha yang berarti kan variable harga cabe yang terjadi di model Fixed Effect lebih baik. Dimana; Ho: tiap propinsi terbukti tidak berpengaruh

Tabel 2

Hasil Uji Hausman Test

Corelated Random Effect-Hausman Test
Equation : Random
\begin{tabular}{llll} 
Test Cross Section Random Effect & & \\
\hline Test Summary & Chi-sq Statistik & Chi-Sq d.f & Prob \\
\hline Cross Section Random & 103,874179 & 4 & 0.0000 \\
\hline Sumber: Data Diolah & & &
\end{tabular}

model random effect lebih baik dan $\mathrm{Ha}$ : terhadaptingkatinflasipropinsidilndonesia. model Fixed Effect lebih baik.

Nilai R-Square sebesar 0,948583 mem-

Berdasarkan hasil uji Chow Test punyai arti bahwa variable pendapatan dan Hausman Tes maka metode estimasi yang digunakan dalam penelitian ini adalah regresi panel data model Fixed Effect. daerah (PDRB), realisasi pengeluaran pemerintah daerah, harga cabe dan harga beras mampu menjelaskan sebesar 94,8583 persen terhadap variasi yang terTabel 3 jadipadatingkatinflasipropinsidilndonesia.

Hasil Estimasi Model Inflasi dengan Regresi Panel data Fixed effect

\begin{tabular}{lcrcc}
\hline Variabel & Koefisien & St. Error & t-Statistik & Prob \\
\hline $\mathrm{C}$ & $-1,459000$ & 0,447293 & $-3,261845$ & 0,0018 \\
$\log (\mathrm{Y})$ & 0,250494 & 0,066144 & 3,787105 & 0,0004 \\
$\log (\mathrm{G})$ & 0,141416 & 0,035620 & 3,970108 & 0,0002 \\
$\log ($ Pcabe $)$ & 0,009507 & 0,010899 & 0,872293 & 0.3865 \\
$\log ($ Pberas $)$ & 0,117611 & 0,037700 & 3,119658 & 0,0028
\end{tabular}

$\begin{array}{lc}\text { R-Square } & 0,948583 \\ \text { AdjustedR-Square } & 0,918590 \\ \text { F-stat } & 31,62676 \\ \text { Prob F } & 0,00000\end{array}$

Dependent Variable : Log(IHK)

Sumber : Data diolah

\section{Hasil dan Pembahasan}

Dengan menggunakan regresi data panel model fixed effect diperoleh hasil sebagai berikut:

Dari tabel di atas terlihat bahwa variable pendapatan daerah (PDRB), realisasi pengeluaran pemerintah daerah dan harga beras terbukti berpengaruh secara

\section{Pendapatan Daerah (PDRB) terhadap Tingkat Inflasi Propinsi}

Berdasarkan hasil estimasi model inflasi dengan regresi data panel fixed effect menunjukkan bahwa koefisien variabel pendapatan daerah (PDRB) bernilai positif yaitu sebesar 0,250494 dan menunjukkan pengaruh yang signifikan pada derajat keyakinan 95 persen $(\alpha=$ 
5\%). Ini dapat diartikan bahwa apabila pendapatan daerah (PDRB) naik sebesar 1 persen maka tingkat harga secara umum akan meningkat sebesar 0,29 persen. Hasil ini sesuai dengan teori bahwa dengan meningkatnya pendapatan maka konsumsi akan meningkat sehingga permintaan agregat juga akan meningkat. Peningkatan permintaan agregat yang tidak diimbangi dengan peningkatan penawaran agregat maka akan menyebabkan terjadinya inflasi karena tarikan permintaan (Demand Pull Inflation). Hasil penelitian ini sesuai juga dengan hasil penelitian dari Evelyn (2012); Jaradat (2011) dan Cerra (2016) yang memberikan hasil yang sama bahwa pendapatan daerah (PDRB) berpengaruh posiif terhadap tingkat inflasi. Hali ini diduga dikarenakan marginal propensity to consume (MPC) masyarakat di Indonesia masih tergolong tinggi. Sehingga kenaikan pendapatan akan direspons dengan kenaikan konsumsi yang tinggi pula. Sehingga pada akhirnya akan mendorong inflasi. Negara sedang berkembang memiliki MPC lebih besar dibandingkan Negara maju (Mankiw, 2015).

\section{Pengeluaran Pemerintah Daerah terha- dap Tingkat Inflasi Propinsi}

Variabel pengeluaran pemerintah daerah terbukti berpengaruh secara signifikan terhadap tingkat inflasi propinsi di Indonesia. Hal ini terlihat dari nilai probability $\mathrm{t}$ sebesar 0.0002 . nilai tersebut lebih kecil dari toleransi kesalahan ( $\alpha$ $=5 \%$ ). Koefisien variabel pengeluaran pemerintah daerah bernilai positif yaitu sebesar 0,141416. Angka ini mempunyai arti bahwa apabila realisasi pengeluaran pemerintah daerah naik sebesar 1 persen maka hal ini akan menyebabkan inflasi meningkat sebesar 0,141416 persen. Hal ini mengindikasikan bahwa pengeluaran pemerintah lebih banyak untuk proyek atau program yang sifatnya tidak produktif. Hasil penelitian ini sejalan dengan hasil penelitian Coutinho (2012) dan penelitian
Aurangzeb (2012) yang memberikan hasi bahwa besarnya pengeluaran pemerintah yang terlihat dari besarnya defisit fiskal berpengaruh positif terhadap tingkat inflasi. Dengan kata lain dengan meningkatnya pengeluaran pemerintah yang tercermin dari peningkatan defisit fiskal maka berpengaruh terhadap peningkatan inflasi.

\section{Harga Pangan terhadap Tingkat Inflasi}

Harga pangan menjadi salah satu faktor yang menjadi penyumbang inflasi di Indonesia. Laporan Bank Indonesia bulan November 2016 menyatakan bahwa inflasi di bulan September 2016 dipicu oleh kenaikan harga pangan terutama harga cabe dan bawang merah (Bank Indonesia, 2016). Dalam penelitian ini harga pangan diwakili oleh harga cabe dan harga beras. Meskipun nilai koefisien dari variable harga cabe menunjukkan nilai positif namun variabel harga cabe tidak berpengaruh secara signifikan terhadap tingkat inflasi propinsi di Indonesia. Hal ini diduga cabe merupakan komoditas pangan yang bukan tergolong kebutuhan pokok. Selain itu kenaikan harga cabe hanya menyebabkan kenaikan harga umum secara sesaat atau musiman saja sehingga tidak berpengaruh secara signifikan terhadap inflasi. Mengingat inflasi adalah kenaikan harga secara umum dan terus menerus, sehingga kenaikan harga sesaat bukanlah dikatakan sebagai inflasi. Berbeda dengan harga cabe yang tidak berpengaruh secara signifikan terhadap tingkat inflasi, harga beras terbukti berpengaruh secara positif dan signifikan terhadap tingkat inflasi propinsi di Indonesia. Nilai koefisien variabel harga beras adalah sebesar 0,117611 . Nilai ini mempunyai arti bahwa apabila harga beras naik sebesar 1 persen maka akan menyebabkan kenaikan harga secara umum (inflasi) sebesar 0,117611 persen. Nasi masih menjadi makanan pokok di sebagian besar masyarakat di Indonesia. Sehingga kenaikan harga beras akan menyebabkan kenaikan harga-harga barang 
lain atau akan menyebabkan kenaikan inflasi. Hasil penelitian ini menguatkan hasil penelitian dari Rangasamy (2010) dan Christoper (2012) yang memberikan hasil bahwa harga pangan mempunyai pengaruh yang kuat dan sumbangan yang besar pada tingkat inflasi.

\section{Penutup}

Dari hasil pembahasan diatas dapat dapat diambil kesimpulan bahwa: tingkat inflasi yang terjadi di 33 propinsi di Indonesia selain disebabkan oleh goncangan dari sisi permintaan yaitu melalui variabel pendapatan dan pengeluaran pemerintah, juga dipengaruhi oleh goncangan dari sisi penawaran yang dalam hal ini adalah harga pangan yang merupakan kebutuhan pokok yaitu harga beras. Variabel pendapatan, pengeluaran pemerintah dan harga beras masing-masing mempunyai pengaruh yang cukup besar terhadap inflasi di 33 propinsi di Indonesia. Sedangkan harga cabe tidak berpengaruh terhadap tingkat inflasi di 33 propinsi di Indonesia diduga karena pengaruh harga cabe terhadap harga barang-barang secara umum hanya bersifat sesaat atau musiman.

Perilaku inflasi di 33 propinsi di Indonesia dipengaruhi oleh sisi permintaan dan penawaran. Dengan kata lain demand pull dan cost push inflation terjadi secara bersama dengan kekuatan yang sama. Hal ini memberikan implikasi kebijakan bahwa kebijakan moneter melalui pengendalian jumlah uang beredar masih efektif untuk pencapaian tujuan stabilitas harga. Namun demikian kebijakan moneter saja tidak akan efektif untuk mencapai target inflasi. Dibutuhkan koordinasi kebijakan antar lembaga atau departemen dalam rangka menjamin ketersediaan kebutuhan pokok seperti komoditi beras, sehingga target inflasi dapat tercapai.

\section{Daftar Pustaka}

Aurangzeb. dan Anwar UI Haq. 2012. Determinant of Inflation in Pakistan. International Journal of Business and Social Science. 2(4).

Bari. Bilqin. 2013. Main Determinant of Inflation in Turkey. International Journal Economics. Res. 41(6): 13-19.

Badan Pusat Statistik. 2015. Statistik Komoditas Pertanian.

Bank Indonesia. 2016. Kajian Ekonomi Regional.

Cerra, Valerie. 2016. Inflation and The Black Market Exchange Rate in a Repressed Market: A Model of Venezuela. IMF Working Paper. 15: 169.

Chavoshzadeh. dan Fariba Tafti. 2012. Determinant of Inflation in Islamic Iran. International Journal of Business and Social Science. 3(6).

Christopher, Adam. 2012. Food Price and Inflation in Tanzania. African Development Bank Working Paper: 163.

Coutinho, Leonor. 2012. Determinant of Growth and Inflation in Southern Mediterranean Countries. MEDPROThechnical Report No.10.

Evelyn, D. Ndidi. 2012. Determinant of Inflation in Nigeria. Journal The Business and Management Review. 3(2).

Fan, Jingwen. dan Patrick Minford. 2016. The Role of Fiskal Policy in Britain's Great Inflation. Journal Economic Modelling (58): 203-218.

Gujarati, Damodar. 2003. Basic Econometrics. McGraw Hill.

Jaradat. Mahmoud, Husein. Ali . and Habib Al Rawahneh. 2011. An Econometric Analysis of Te Determinant of Inflation in Jordan. Middle Eastern Finance and Economics. 15. 
Mankiw, Gregory. 2016. Macro Economics. Nine edition. Worth Publisher.

Miskin, Frederick. 2013. The Economics of Money, Banking, and Financial Markets. Perason.

Rangasamy, Logan. 2010. Food Inflation in South Africa: Some Implications for Economic Policy. Working Paper.

Widarjono, Agus. 2016. Ekonometrika Pengantar dan Aplikasinya. UPP STIM YKPN. 